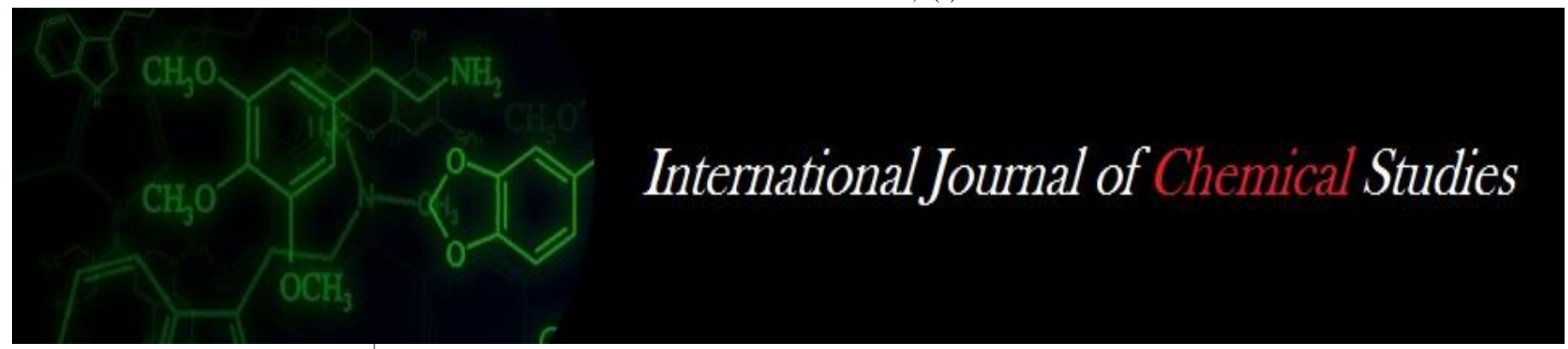

P-ISSN: 2349-8528

E-ISSN: 2321-4902

www.chemijournal.com

IJCS 2020; 8(2): 1641-1644

(C) 2020 IJCS

Received: 12-01-2020

Accepted: 16-02-2020

Vikas Belwal

Department of Genetics and Plant Breeding, G.B. Pant

University of Agriculture and

Technology, Pantnagar,

Uttarakhand, India

Sarfraz Ahmad

Department of Genetics and Plant Breeding, G.B. Pant

University of Agriculture and Technology, Pantnagar,

Uttarakhand, India
Corresponding Author:

Vikas Belwal

Department of Genetics and Plant Breeding, G.B. Pant

University of Agriculture and

Technology, Pantnagar,

Uttarakhand, India

\section{Association of quantitative and qualitative characters of sugarcane under water logging conditions}

\author{
Vikas Belwal and Sarfraz Ahmad
}

DOI: https://doi.org/10.22271/chemi.2020.v8.i2y.8995

\begin{abstract}
Study on association of quantitative and qualitative characters of sugarcane under water logging conditions comprises 14 diverse released cultivar and advance lines along with four water logging tolerance checks. Field evaluation was carried out in Randomize Block Design for thirteen different morphological and quality parameters. Analysis of variance revealed significant differences among all the genotypes for the characters studied. Correlation coefficient studies indicated that number of tillers and sucrose percent (at genotypic level) and germination percentage was significant and positively correlated with cane yield. A high significant positive correlation with number of millable canes and commercial cane sugar yield was also observed. No significant association of cane yield with any of the quality characters was found. Path analysis revealed that commercial cane sugar percent, juice purity, juice brix, single cane weight and number of millable canes had high positive direct effect while sucrose percent revealed to have high negative direct effect on cane yield. Results from the analysis indicated that selection programme for high yielding water logging tolerant clones would be effective if it was based on number of millable canes, single cane weight, purity percent and commercial cane sugar percent.
\end{abstract}

Keywords: Correlation, path analysis, sugarcane, water logging

\section{Introduction}

Sugarcane is an important commercial crop which is grown in tropical and subtropical climate the word over. It belongs to the family Gramineae. The important sugarcane growing countries are India, Brazil, Cuba, China, USA, Mexico, France, Germany and Australia. In India, the major sugarcane growing states are Uttar Pradesh, Maharashtra, Tamil Nadu, Karnataka, Bihar, Punjab and Haryana. Sucrose is the main product of sugarcane. The other products are green tops, bagasse, molasses, filter mud, stubbles and dry leaves. There are three cultivated species of sugarcane viz. Saccharum officinarum $(2 \mathrm{n}=118)$, Saccharum sinense $(2 \mathrm{n}=118)$ and Saccharum barberi $(2 \mathrm{n}=82-124)$ and two wild species viz. Saccharum spontaneum $(2 \mathrm{n}=40$ $128)$ and Saccharum robustum $(2 n=60-194)$. Sugarcane is grown under different types of soil and water regimes. Being a long duration crop it faces various natural calamities especially biotic/abiotic stresses during its life cycle. In India considerable area under sugarcane is prone to water logging, adversely affects cane productivity and quality. In general water logging induces anaerobic condition in soil. Moreover, excess rainfall during late summer and monsoon quite often creates flooding problem and rears have no options but to use flood affected sugarcane. The yield and quality characters exhibit various types of interrelationship amongst themselves. The correlation between characters and the contribution of each character towards the cane yield could be influenced by several characters. Therefore it is important to study the relationship between different characters and with cane yield as cane yield is dependent on several characters. To understand interrelationship of a dependent character with several independent characters, path coefficient analysis is performed to partition the correlation coefficient into direct and indirect effects. This helps in formulation of suitable selection strategies for seeking genetic improvement of population. So in the present investigation, an effort has been made to study association of quantitative and quality characters of different sugarcane varieties under water logging conditions. 


\section{Materials and Methods}

The present investigation entitled "Association of quantitative and quality Characters of sugarcane (Saccharum species complex) under water logging conditions" was conducted at the Sugarcane Breeding Experimental Block of Norman Borlaug Crop Research Centre, G. B. Pant University of Agriculture and Technology, Pantnagar, India, during 20102011. Eighteen genotypes along with four checks viz., CoS 97264, CoSe 96436, UP 9530 and BO 91 designated for water logging conditions, were evaluated. All the genotypes included in the study were of diverse origin (Table 1). The field experiments was laid out in Randomize Block Design (RBD) with two replications under water logging, imposed twice (for three days during July 18-20, 2010 at $60 \mathrm{~cm}$ water depth and then for four days from 18 to 21 August, 2010 with the water depth of $69.5 \mathrm{~cm}$ ). Data were recorded on 14 characters (9 morphological and 5 quality traits). The morphological characters includes germination per cent, number of tillers, number of millable canes (NMC), cane height $(\mathrm{m})$, cane thickness $(\mathrm{cm})$, single cane weight $(\mathrm{kg})$, juice weight (kg), cane yield (tonnes per hectare), commercial cane sugar yield (CCS yield) (tonnes per hectare) and quality traits were as juice brix per cent, sucrose per cent, juice purity per cent, juice extraction per cent, commercial cane sugar per cent (CCS \%). Standard procedure had been used during collection of data on morphological and quality traits.

\section{Correlation coefficient}

The correlation coefficient was calculated based on the mean values of different characters for each entry as:

$$
r=\frac{\left(\mathrm{X}_{i}-\overline{\mathrm{X}}\right)\left(Y_{i}-\overline{\mathrm{Y}}\right)}{\sqrt{\left(X_{i}-\overline{\mathrm{X}}\right)^{2}\left(Y_{i}-\overline{\mathrm{Y}}\right)^{2}}}
$$

Where, $r$ is correlation coefficient between character $\mathrm{X}$ and $\mathrm{Y}$. Correlation coefficients between all possible pairs of characters were calculated at genotypic and phenotypic level. The analysis of variance and covariance was used for the estimation of correlation coefficient in the following manner as suggested by Searle ${ }^{[11]}$.

1. Phenotypic correlation coefficient between character $\mathrm{x}$ and $\mathrm{y}$

$$
r_{x y(p)}=\frac{\operatorname{Cov} \cdot x y(p)}{\sqrt{\operatorname{Var} \cdot x(p) \operatorname{Var} \cdot y(p)}}
$$

2. Genotypic correlation coefficient between character $\mathrm{x}$ and $y$

$$
r_{x y(g)}=\frac{\operatorname{Cov} \cdot x y(g)}{\sqrt{\operatorname{Var} \cdot x(g) \operatorname{Var} \cdot y(g)}}
$$

\section{WHERE}

Cov.xy(p) and Cov.xy(g) denotes the phenotypic and genotypic covariance between characters $\mathrm{x}$ and $\mathrm{y}$ respectively. $\operatorname{Var} . x(p)$ and $\operatorname{Var} . y(p)$ denotes phenotypic variance and $\operatorname{Var} . \mathrm{x}(\mathrm{g})$ and $\operatorname{Var} . \mathrm{y}(\mathrm{g})$ denotes genotypic variance for characters $\mathrm{x}$ and $\mathrm{y}$ respectively.

\section{Path coefficient analysis}

The phenotypic and genotypic correlation coefficient were further partitioned into direct and indirect effect with the help of path coefficient analysis as suggested by Wright, 1921 [17] and elaborated by Dewey and $\mathrm{Lu}{ }^{[2]}$. Cane yield was considered as dependent variable as factors assumed to be influenced by the other characters called independent variables as causes.

Table 1: List of clones/ genotypes used in experiment

\begin{tabular}{|c|c|c|c|c|c|}
\hline $\begin{array}{c}\text { S. } \\
\text { N. }\end{array}$ & Clones & Origin & $\begin{array}{c}\text { S. } \\
\text { N. }\end{array}$ & Clones & Origin \\
\hline 1 & CoS 767 & Shahjahanpur & 10 & Co 1148 & Coimbatore \\
\hline 2 & CoPant2218 & Pantnagar & 11 & CoPant 84211 & Pantnagar \\
\hline 3 & $\begin{array}{c}\text { CoPant } \\
90223\end{array}$ & Pantnagar & 12 & CoK 16/05 & Kashipur \\
\hline 4 & CoPant 3230 & Pantnagar & 13 & CoPant 5224 & Pantnagar \\
\hline 5 & CoPant 5222 & Pantnagar & 14 & CoJ 64 & Jalandhar \\
\hline 6 & $\begin{array}{c}\text { CoPant } \\
97222\end{array}$ & Pantnagar & 15 & $\begin{array}{c}\text { CoS 97264 } \\
\text { (Check) }\end{array}$ & Shahjahanpur \\
\hline 7 & CoPant 3219 & Pantnagar & 16 & $\begin{array}{c}\text { CoSe 96436 } \\
\text { (Check) }\end{array}$ & Seorahi \\
\hline 8 & CoS 96268 & Shahjahanpur & 17 & UP 9530 (Check) & Uttar Pradesh \\
\hline 9 & $\begin{array}{c}\text { CoPant } \\
99214\end{array}$ & Pantnagar & 18 & BO 91 (Check) & Bihar \\
\hline
\end{tabular}

\section{Results and Discussions}

Analysis of variance revealed highly significant variability for all the characters under study indicating existence of good amount of phenotypic variability. Further, the genotypes differed significantly among each other with regard to all the characters except for juice brix. The phenotypic and genotypic correlation coefficients for the characters are presented in table 2 . The results for path coefficient analysis for cane yield are given in table 3 .

\section{Correlation between characters}

In general the estimates of genotypic correlations were higher than their respective phenotypic correlations. Directions of genotypic and phenotypic correlation were almost same for all the character combinations. Number of tillers and sucrose percent (at genetic level only) and germination percentage were found significantly and positively correlated with cane yield. There was also highly significant positive correlation with number of millable canes and CCS yield. There was no significant correlation of cane yield observed with any of the quality characters. It is obvious that germination percent, millable cane number and CCS yield can be considered together in a positive direction towards an ultimate aim of developing high yielding sugarcane clone. CCS yield at both genotypic and phenotypic level was found to be significantly and positively correlated with germination percent, number of tillers, NMC, sucrose percent, purity percent and CCS percent and cane yield.

Germination percent showed a significant positive correlation with number of tillers, cane yield and CCS yield this was in accordance with Mishra et al. ${ }^{[6]}$ and Thippeswamy et al. ${ }^{[15]}$. Number of tillers had positive correlation with NMC, sucrose, purity percent, CCS percent, cane yield and CCS yield, similar as found earlier by Mishra et al. ${ }^{[6]}$ and Singh and Singh ${ }^{[14]}$ number of tillers also found negatively correlated with can weight. Number of millable canes showed significant negative correlation with cane diameter, cane weight and juice weight which was similar to the results of Das et al. ${ }^{[1]}$. Number of millable canes had shown a positive correlation with sucrose, CCS per cent, cane yield and CCS yield. This was in conformity with Rahman et al. ${ }^{\text {[7]. A }}$ perusal of result for cane height revealed that its correlation was non significant with any traits. Non significant correlation of cane height with cane weight was reported earlier by Setia ${ }^{[12]}$ and Verma ${ }^{[16]}$. Cane thickness had shown significant positive correlation with cane weight and juice 
weight. It was in general agreement with Rahman et al. ${ }^{[7]}$ and Ishaq et al. ${ }^{[4]}$. Cane thickness showed significant negative correlation values at genotypic level with sucrose, purity per cent, CCS per cent and CCS yield. This was general disagreement with the literature reviewed. Cane height showed significant negative correlation with sucrose, CCS per cent and CCS yield at genotypic level. Juice weight also had significant negative correlation with purity per cent and CCS per cent while was positively correlated with extraction per cent. Brix was positively correlated with extraction percent; also it had significant negative correlation with sucrose, purity percent and CCS per cent. Sucrose percent had significant positive correlation with purity percent, CCS percent, cane yield and CCS yield also reported earlier by Singh et al. ${ }^{[13]}$ and Jain et al. ${ }^{[5]}$. Juice purity had shown significant positive association with CCS percent and CCS yield as reported by Rajib Das et al. ${ }^{[8]}$. CCS percent had revealed significant positive correlation with CCS yield. This was in conformity with Singh et al. ${ }^{[13]}$ and Das et al. ${ }^{[1]}$. Cane yield had shown high correlation with CCS yield as reported by Reddy and Somarajan ${ }^{[10]}$ and Reddy and Khan ${ }^{[9]}$. There is no significant association of cane yield was observed with quality characters, it was also reported earlier by Jain et al. ${ }^{[5]}$.

\section{Path analysis}

The cane yield was dependent trait and many characters affect or show association with it. Thus, in order to determine the contribution of various characters towards yield, it was necessary that the correlation between yield and component characters be partitioned into direct and indirect effects. Path analysis revealed that CCS percent (5.275) exerted a high magnitude of positive direct effect on cane yield followed by juice brix percent (4.92), purity percent (3.617), single cane weight (1.81), NMC (1.66), juice extraction percent (1.061), cane height (0.032) and cane diameter (0.01). Sucrose percent (-7.365) exerted high negative direct effect on cane yield followed by juice weight $(-1.39)$, number of tillers $(-0.068)$ and germination percent $(-0.0006)$. These results were close to the findings of Singh et al. ${ }^{[13]}$, Rajib Das et al. ${ }^{[8]}$, Singh and Singh ${ }^{[14]}$ and Hooda et al. ${ }^{[3]}$.

The indirect effects of germination percent on cane yield were positive through CCS percent (1.927), purity percent (1.002), number of millable canes (0.732), juice weight (0.236) and cane height (0.003). Number of tillers had indirect effect through juice weight $(0.561)$, number of millable cannes (1.067), purity percent (2.029) and CCS percent (3.042) were positive. Number of millable cane had indirect positive effect through juice brix (0.219), juice weight (0.74), purity percent (1.228) and CCS percent (2.723). Cane height had indirect positive effect through cane diameter (0.0003), number of tillers (0.0005), juice weight (0.171), CCS percent (0.231), cane weight (0.48) and juice sucrose (1.91). Cane thickness showed positive indirect effect through cane height (0.001), cane weight (1.321), juice brix (1.434) and sucrose percent (2.836). Cane weight on cane yield had positive indirect effects through germination (0.0009), cane thickness (0.007), cane height (0.008), number of tillers (0.034), juice extraction percent (0.321) and sucrose percent (3.172). Juice weight had indirect positive effect through cane diameter (0.006), number of tillers (0.027), juice extraction (0.891), cane weight (1.144), brix (1.512) and sucrose percent (2.028). The positive indirect effect of sucrose percent on cane yield were through juice weight $(0.382)$, juice brix $(0.314)$, number of millable cane (0.942), juice purity (2.227) and CCS percent (4.845) positive. Juice purity showed indirect positive effect through number of millable canes (0.563), juice weight (0.589) and CCS percent (4.626). However, CCS percent showed indirect effect through juice weight (0.528), number of millable cane (0.857) and purity percent (3.172) on can yield. Juice extraction percent also showed positive indirect effects through cane thickness (0.003), number of tillers (0.011), cane weight (0.204), sucrose percent (0.55) and juice brix (2.061). The residual factor 0.0014 indicated that 0.14 percent contribution towards cane yield was through unexplained factors which were not included in causal relationship for path analysis.

The study of correlation and path analysis shows that, if the correlation between cane yield and a character is due to direct effect of a character, it reveals true relationship between them and direct selection for this trait will be rewarding for the trait improvement. If the correlation is mainly due to indirect effects of the character through another component trait, indirect selection through such trait will help in yield improvement. If the direct effect is positive and high, but the correlation is negative, in such situation direct selection for such trait should be practiced to reduce the undesirable indirect effect. In the present investigation, path coefficient analysis has established the importance of some characters in the selection programme but also it has revealed that some characters were not as important as may be concluded merely by seeing the correlations.

Table 2: Genotypic and Phenotypic correlation between different characters in Sugarcane

\begin{tabular}{|c|c|c|c|c|c|c|c|c|c|c|c|c|c|c|c|}
\hline Characters & $\begin{array}{l}\text { Corr. } \\
\text { Coeff. }\end{array}$ & $\begin{array}{c}\text { Germi- } \\
\text { nation \% }\end{array}$ & $\begin{array}{l}\text { No. of } \\
\text { tillers }\end{array}$ & NMC & $\begin{array}{c}\text { Cane } \\
\text { height }\end{array}$ & $\begin{array}{c}\text { Cane } \\
\text { thickness }\end{array}$ & $\begin{array}{c}\text { Single } \\
\text { Cane } \\
\text { weight }\end{array}$ & $\begin{array}{c}\text { Juice } \\
\text { weight }\end{array}$ & $\begin{array}{c}\text { Juice } \\
\text { Brix \% }\end{array}$ & $\begin{array}{l}\text { Juice } \\
\text { sucrose }\end{array}$ & $\begin{array}{c}\text { Purity } \\
\%\end{array}$ & CCS \% & \begin{tabular}{|c|} 
Juice \\
extraction \\
$\%$
\end{tabular} & $\begin{array}{l}\text { Cane } \\
\text { yield }\end{array}$ & $\begin{array}{l}\text { CCS } \\
\text { yield }\end{array}$ \\
\hline \multirow{2}{*}{$\begin{array}{c}\text { Germination } \\
\%\end{array}$} & $\mathrm{rg}_{\mathrm{g}}$ & - & $0.65 * *$ & 0.46 & 0.08 & -0.03 & -0.16 & -0.16 & -0.07 & 0.46 & 0.29 & 0.39 & -0.12 & $0.58^{*}$ & $0.58^{*}$ \\
\hline & $\mathrm{r}_{\mathrm{p}}$ & - & $0.68 * *$ & 0.43 & 0.10 & -0.07 & -0.13 & -0.17 & -0.05 & 0.32 & 0.26 & 0.35 & -0.14 & $0.47 *$ & $0.50 *$ \\
\hline \multirow{2}{*}{ No. of tillers } & $\mathrm{rg}_{\mathrm{g}}$ & & - & 0.70 *** & -0.04 & -0.41 & $-0.60 * *$ & -0.42 & -0.38 & $0.68^{* * *}$ & $0.60 * *$ & 0.66 ** & -0.16 & $0.55^{*}$ & $0.71 * *$ \\
\hline & $r_{p}$ & & - & 0.60 *** & 0.01 & -0.39 & -0.45 & -0.38 & -0.28 & 0.38 & $0.53 *$ & $0.52 *$ & -0.18 & 0.41 & $0.54 *$ \\
\hline \multirow{2}{*}{ NMC } & $\mathrm{rg}_{\mathrm{g}}$ & & & - & -0.16 & $-0.67 * *$ & $-0.86 * *$ & $-0.55^{*}$ & 0.07 & $0.73 * *$ & 0.37 & $0.56^{*}$ & -0.15 & $0.81 * *$ & $0.84 * *$ \\
\hline & $\mathrm{r}_{\mathrm{p}}$ & & & - & -0.15 & $-0.65^{* *}$ & $-0.76^{* * *}$ & $-0.52 *$ & -0.03 & $0.49^{*}$ & 0.32 & $0.49 *$ & -0.11 & $0.74 * *$ & $0.76^{* *}$ \\
\hline \multirow{2}{*}{ Cane height } & $r_{g}$ & & & & - & 0.04 & 0.29 & -0.15 & -0.41 & -0.37 & 0.02 & -0.18 & -0.40 & 0.03 & -0.09 \\
\hline & $r_{p}$ & & & & - & -0.02 & 0.26 & -0.09 & -0.27 & -0.20 & 0.09 & -0.09 & 0.33 & -0.01 & -0.04 \\
\hline \multirow{2}{*}{$\begin{array}{c}\text { Cane } \\
\text { thickness }\end{array}$} & $\mathrm{rg}_{\mathrm{g}}$ & & & & & - & $0.79 * *$ & $0.64 * *$ & 0.41 & -0.60 ** & $-0.57 *$ & $-0.61^{* *}$ & 0.29 & -0.32 & $-0.54 *$ \\
\hline & $\mathrm{r}_{\mathrm{p}}$ & & & & & - & $0.69 * *$ & $0.62 * *$ & 0.25 & -0.27 & -0.42 & -0.39 & 0.31 & -0.29 & -0.39 \\
\hline \multirow{2}{*}{$\begin{array}{c}\text { Single Cane } \\
\text { weight }\end{array}$} & $\mathrm{rg}_{\mathrm{g}}$ & & & & & & - & $0.61 * *$ & -0.09 & $-0.65 * *$ & -0.31 & $-0.50 *$ & 0.13 & -0.40 & \begin{tabular}{|l|}
$-0.54 *$ \\
\end{tabular} \\
\hline & $r_{p}$ & & & & & & - & $0.65 * *$ & 0.001 & -0.31 & -0.23 & -0.32 & 0.09 & -0.14 & -0.26 \\
\hline \multirow{2}{*}{ Juice weight } & $\mathrm{r}_{\mathrm{g}}$ & & & & & & & - & 0.43 & -0.43 & $-0.48^{*}$ & $-0.47 *$ & $0.87 * *$ & -0.31 & -0.45 \\
\hline & $r_{p}$ & & & & & & & - & 0.26 & -0.19 & -0.38 & -0.32 & $0.82 * *$ & -0.14 & -0.25 \\
\hline \multirow{2}{*}{ Juice Brix \% } & $\mathrm{rg}_{\mathrm{g}}$ & & & & & & & & - & $-0.56^{* * *}$ & $-0.89 * *$ & -0.75 ** & $0.60 * *$ & \begin{tabular}{|c|}
-0.01 \\
\end{tabular} & -0.40 \\
\hline & $\mathrm{r}_{\mathrm{p}}$ & & & & & & & & - & 0.28 & $-0.71 * * \mid$ & -0.16 & 0.35 & 0.08 & -0.01 \\
\hline
\end{tabular}




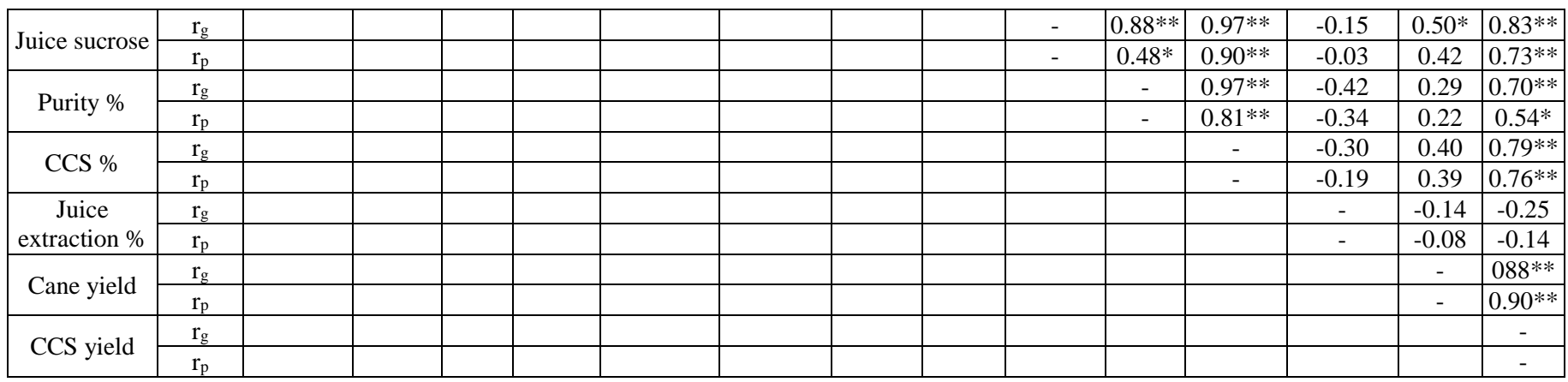

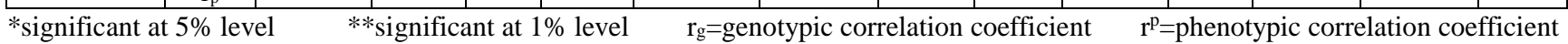

Table 3: Path coefficient analysis showing direct and indirect effect of various characters on cane yield at phenotypic level

\begin{tabular}{|c|c|c|c|c|c|c|c|c|c|c|c|c|c|c|}
\hline \multirow[b]{2}{*}{ Characters } & \multirow[b]{2}{*}{$\begin{array}{c}\text { Correlation } \\
\text { with cane } \\
\text { yield }\end{array}$} & \multirow[b]{2}{*}{$\begin{array}{l}\text { Direct } \\
\text { effect }\end{array}$} & \multicolumn{12}{|c|}{ Indirect effect via } \\
\hline & & & $\begin{array}{c}\text { Germination } \\
\%\end{array}$ & $\begin{array}{l}\text { No. of } \\
\text { tillers }\end{array}$ & NMC & $\begin{array}{c}\text { Cane } \\
\text { height }\end{array}$ & $\begin{array}{c}\text { Cane } \\
\text { diameter }\end{array}$ & \begin{tabular}{|c|} 
Single \\
Cane \\
weight
\end{tabular} & $\begin{array}{c}\text { Juice } \\
\text { weight }\end{array}$ & $\begin{array}{l}\text { Juice } \\
\text { brix \% }\end{array}$ & $\begin{array}{c}\text { Sucrose } \\
\%\end{array}$ & Purity & CCS \% & \begin{tabular}{|c|c|c} 
Juice \\
extraction \\
$\%$
\end{tabular} \\
\hline $\begin{array}{c}\text { Germination } \\
\%\end{array}$ & * & .0006 & - & -0.045 & 0.732 & 0.003 & -0.0005 & -0.257 & 0.236 & -0.261 & -2.685 & 1.002 & 1.927 & -0.140 \\
\hline No of tillers & 0461 & 2068 & 00 & - & 1.067 & -0.0002 & -0.004 & -0.924 & 0.561 & -1.491 & -3.567 & 2.029 & 3.042 & -0.183 \\
\hline NMMC & & & & .043 & - & -0.004 & & -1.438 & 0.740 & 0.219 & & 28 & & -0.131 \\
\hline Cane & .024 & 32 & -()$_{2}$ & 0.0005 & $\begin{array}{c}- \\
0.253 \\
\end{array}$ & - & 0.0003 & 0.480 & 0.171 & -1.521 & 1.910 & 0.231 & -0.640 & -0.388 \\
\hline $\begin{array}{c}\text { Cane } \\
\text { diameter }\end{array}$ & 303 & 0.010 & -0.00003 & -0.027 & \begin{tabular}{c|}
- \\
1.090 \\
\end{tabular} & 0.001 & - & 1.321 & -0.873 & 1.434 & 2.836 & -1.758 & -2.532 & 0.321 \\
\hline $\begin{array}{c}\text { Single Cane } \\
\text { weight }\end{array}$ & -0.220 & 1.810 & .0009 & 0.034 & \begin{tabular}{c|}
- \\
1.318 \\
\end{tabular} & 0.008 & 0.007 & - & -0.879 & -0.067 & 3.172 & -0.999 & -2.108 & 0.119 \\
\hline Juice & -( & 390 & 0.0001 & 7 & $\mid \begin{array}{c}- \\
0.884\end{array}$ & -0.004 & 06 & 1.144 & - & 1.512 & 2.028 & -1.533 & -2.006 & 0.891 \\
\hline Juice brix $\%$ & 056 & 4.920 & 0.00003 & 0.020 & 0.074 & -0.010 & 0.003 & -0.024 & -0.427 & - & -0.471 & -2.702 & -1.770 & 0.444 \\
\hline Sucrose $\%$ & & \begin{tabular}{|l|}
-7.365 \\
\end{tabular} & -0.0002 & -0.032 & 0.942 & \begin{tabular}{|l|}
-0.008 \\
\end{tabular} & -0.003 & \begin{tabular}{|l|}
-0.779 \\
\end{tabular} & 0.382 & 0.314 & - & 2.227 & 4.845 & -0.079 \\
\hline & & & 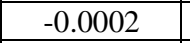 & .038 & 0.563 & \begin{tabular}{|l|}
0.002 \\
\end{tabular} & -0.005 & -0.500 & 0.589 & -3.675 & -4.534 & - & 4.626 & -0.401 \\
\hline $\mathrm{CC}$ & & 75 & & 39 & 0.857 & -0.003 & & -0.723 & 0.528 & -1.651 & -6.766 & 3.172 & - & -0.250 \\
\hline $\begin{array}{c}\text { Juice } \\
\text { extraction \% }\end{array}$ & -0.104 & 1.061 & -0.0009 & 0.011 & $\begin{array}{c}- \\
0.206 \\
\end{array}$ & -0.011 & 0.003 & 0.204 & -1.166 & 2.061 & 0.550 & -1.366 & -1.244 & - \\
\hline
\end{tabular}

Residual factor $=0.0014$

\section{References}

1. Das PK, Jena BC, Nayak N. Character association and path analysis of sugar yields in sugarcane. Indian Sugar. 1997; 46:805-808.

2. Dewey DR, Lu KH. A correlation and path coefficient analysis of components of crested wheat grass seed production. Agron. J. 1959; 51(9):515-518.

3. Hooda RS, Babu CN, Khairwal IS. Association and path analysis of nine characters in progenies of four sugarcane crosses at settling stage. Indian J Agric. Sci. 1979; 49:12.

4. Ishaq MN, Echekwu CA, Olorunju PE, Gupta US. Correlation and correlated responses in sugarcane (Saccharum officinarum L.). Nigerian Agric. Jour. 2002; 33:102-108.

5. Jain P, Rishi Pal, Kadian SP, Saini ML. Character relationship among quality and agronomical traits in sugarcane. Indian Sugar. 2002; 52(9):723-726.

6. Mishra PK, Mishra A, Mishra P. Character association and its use in sugarcane classification. Indian Sugar. 2006; 55(12):19- 24.

7. Rahman MM, Nahar SMN, Rahima MA, Mahmud F, Tareque HM. Correlation and path analysis in some promising clones of sugarcane. Indian Sugar. 2008; 58(8):31-36.

8. Rajib Das, Ghoshal SK, Ray BR, Mazumdar D. Study of correlation and path analysis in relation to cane and sugar yield of sugarcane. Sugar Tech. 2007; 9(4):293-299.
9. Reddy KR, Khan AQ. Association among yield and quality characters in sugarcane. Indian J Agric. Sci. 1984; 54(8):645-650.

10. Reddy OUK, Somarajan KG. Genetic variability and character association in interspecific hybrids in sugarcane. Indian J of Gen. and Plant Breed. 1993; 54(1):32-36.

11. Searle SR. Phenotypic, genptypic and environmental correlations. Biometrica. 1961; 17:475-480.

12. Setia AK, Bhatnagar PK, Singh A, Shrotia PK. Correlation and path coefficient analysis for yield in sugarcane. Indian J sugarcane Tec. 2001; 16(2):5.

13. Singh A, Bhatnagar PK, Khan AQ, Shrotia PK. Association of quality character with cane and commercial cane sugar yields in sugarcane. Sugar tech. 2003; 5(3):197-198.

14. Singh R, Singh JRP. Path analysis in sugarcane under waterlogged condition. Jour of Applied Biol. 1999; (2):137-139.

15. Thippeswamy S, Kajjidoni ST, Salimath PM, Goud JV. Correlation and path analysis for cane yield, juice quality and their component traits in sugarcane. Sugar tech. 2003; 5(1/2):65-72.

16. Verma HP. A study of certain correlation between yield and growth factors in sugarcane. Proc. 31 Annual Convention of sugarcane Technologists Association of India, 1963, 103-106.

17. Wright S. Correlation and causation. J Agric. Res. 1921; 20:557-585. 